\title{
FIRST RECORD FOR CATHARTUS QUADRICOLLIS AND CALLOSOBRUCHUS MACULATUS CULTURES ATTACKED BY THE MITE PYEMOTES TRITICI
}

\author{
PRIMER REGISTRO DE COLONIAS DE CATHARTUS \\ QUADRICOLLIS $Y$ CALLOSOBRUCHUS MACULATUS ATACADAS \\ POR PYEMOTES TRITICI
}

\author{
Carlos Romero Ferreira de Oliveira ${ }^{1}$; Adalberto Hipólito de Sousa ${ }^{2}$; Marco Aurélio \\ Guerra Pimentel ${ }^{2}$; Cláudia Helena Cysneiros Matos ${ }^{1}$; Lêda Rita D’Antonino Faroni ${ }^{3}$
}

\begin{abstract}
It is recorded the occurrence of Pyemotes tritici (Lagréze-Fossat \& Montagné) on Cathartus quadricollis (Guérin-Méneville) and Callosobruchus maculatus (Fabricius), reducing insect's populations in laboratory conditions. This mite was observed feeding on larvae and pupae of $C$. quadricollis, and adults of $C$. maculatus. The mite toxin quickly paralyzed larvae and adults attacked. The mite $P$. tritici is a lethal problem for mass rearing of insects and its effective eradication ultimately depends on the periodic monitoring of the insect colonies. As result, the mite $P$. tritici can be a new alternative for the biological control of $C$. quadricollis and C. maculatus in stored products. However, this possibility must be better understood before it could be recommended, because Pyemotes sp. could also cause dermatitis in the humans.
\end{abstract}

Key words: Acari, parasitism, biological control, Coleoptera, stored grains.

\section{RESUMEN}

Se registra la ocurrencia de Pyemotes tritici (Lagréze-Fossat \& Montagné) sobre Cathartus quadricollis (Guérin-Méneville) y Callosobruchus maculatus (Fabricius), reduciendo las poblaciones de estos insectos bajo condiciones de laboratorio. Este ácaro fue observado alimentándose sobre larvas y ninfas de $\mathrm{C}$. quadricollis y de adultos de $\mathrm{C}$. maculatus. La toxina del ácaro paraliza totalmente las larvas y los adultos atacados. El ácaro $\mathrm{P}$. tritici es un problema letal para producción masal de insectos, y su erradicación efectiva depende de una supervisión periódica de las colonias de insectos. De acuerdo con los resultados, el ácaro P. tritici puede ser una nueva alternativa para el control biológico de $\mathrm{C}$. quadricollis y de $\mathrm{C}$. maculatus en productos almacenados. Sin embargo, esta posibilidad necesita de estudios adicionales para posterior recomendación, visto que varias especies de Pyemotes también pueden causar dermatitis en seres humanos.

Palabras clave: Acari, parasitismo, control biológico, Coleoptera, granos almacenados.

The species of Pyemotes are leading a parasitoid mode of life, particularly favoring the various developmental stages of mostly insects. Owing to their parasitoid mode of life and aggressive attack on their host they might be considered as potential tools in biological control programs. The mite Pyemotes tritici (Lagréze-Fossat \& Montagné) has been studied as a potential biological control agent because of its high reproductive potential, short life cycle and wide host range (Moser et al., 1971; Bruce \& Lecato, 1979; Bruce, 1983; Bruce \& Wrensch, 1990).

The mite $P$. tritici is associated with virtually every insect order. More than 100 insect species

1 Universidade Federal Rural de Pernambuco, Unidade Acadêmica de Serra Talhada, CEP 56900-000, Serra Talhada-PE, Brasil. E-mail: romero@uast.ufrpe.br; E-mail: c.helena@uast.ufrpe.br

2 Universidade Federal de Viçosa, Departamento de Biologia Animal, Setor de Entomologia, CEP 36570-000, Viçosa-MG, Brasil.E-mail: adalberto@insecta.ufv.br; E-mail: marco@vicosa.ufv.br

3 Universidade Federal de Viçosa, Departamento de Engenharia Agrícola, CEP 36570-000, Viçosa-MG, Brasil. E-mail: 1faroni@ufv.br 
are known hosts of $P$. tritici among Coleoptera, Hymenoptera, Lepidoptera, Homoptera, Strepspitera and Diptera, but it is primarily associated with Coleoptera and Lepidoptera (Cross et al., 1975; Bruce \& Lecato, 1980; Bruce \& Wrensch, 1990). In most cases, it was found on rearing mass in laboratories and stored products, attacking larval stages of Plodia interpunctella (Hübner), Ephestia cautella (Walker), Oryzaephilus mercator (Fauvel), Lasioderma serricorne (Fabricius), Anagasta kuehniella (Zeller) and Sitophilus zeamais Motschulsky, and adults of Tribolium castaneum (Herbst), Sitotroga cerealella (Oliver) and Acanthoscelides obtectus (Say) (Bruce \& Lecato, 1979; Bruce \& Lecato, 1980; Tawfik et al., 1981; Hoschele \& Tanigoshi, 1993; Oliveira \& Matos, 2006; Cunha et al., 2006; Oliveira et al., 2007).

The biology of this mite species was studied by many researches (Moser, 1975; Bruce \& Lecato, 1980; Bruce, 1983; Bruce \& Wrensch, 1990). Due to its short life cycle period and a high reproductive potential, $P$. tritici population can easily increase. Females of this mite species produced up to 355 offspring. Males emerged faster than females (Tomalski et al., 1988; Bruce \& Wrensch, 1990; Hoschele \& Tanigoshi, 1993). P. tritici is well characterized by two aspects: its physogastric process and suppression of immature stages. Physogastry is the extensive enlargement of a female's body during feeding period. During this phase, development of offspring begins. Development takes place inside the enlarged opisthosomal sac of these now gravid females with eggs proceeding directly to adults. The second contributes to the shortening of its life cycle, because this mite does not pass through the nymphal stages (Bruce, 1984; Gerson \& Smiley, 1990; Evans, 1992).

Immediately upon emergency, females of P. tritici are mated and thus almost always disperse as fertilized adults. They can tightly attach to the host body and paralyze it by injecting its venom (toxins). The attachment is explained by their capability for easily piercing the cuticle with their chelicerae in order to suck the host (Tawfik et al., 1981). In addiction, the venom of a single female is enough to paralyze an insect host (Tomalski et $a l ., 1988)$, even if it is not proper for reproduction (Bruce \& Wrensch, 1990). As result, this generalist behavior and efficient killing are strong points that must be considered for a promising biological control strategy.
We used one strain of the "squarenecked grain beetle" Cathartus quadricollis (Guérin-Méneville) originally collected from maize on farm wood store in Aguanil, Minas Gerais, Brazil. The strain of the "cowpea weevil" Callosobruchus maculatus (Fabricius) was collected on laboratory cultures in Campos dos Goytacazes, Rio de Janeiro, Brazil. These populations were reared in glass bottles $(1.5 \mathrm{~L})$ in the laboratory $\left(28 \pm 2{ }^{\circ} \mathrm{C}, 70 \pm 5 \%\right.$ r.h. $)$. Broken corn grains were used as food (13\% m.c.) for C. quadricollis and whole beans for C. maculatus (13\% m.c.). Grains were previously disinfected and kept at $-18{ }^{\circ} \mathrm{C}$ to avoid reinfestation.

Cultures of the C. quadricollis and of the C. maculatus, stored in the Laboratório de Grãos Armazenados (Departamento de Engenharia Agrícola-Universidade Federal de Viçosa, Brasil) were heavily parasitized by the mite $P$. tritici. Subsequent examination of hosts showed that all were parasitized. We observed high mortality levels of C. quadricollis and C. maculatus. After carefully analysis, we concluded it was due to the high increased population and parasitism of $P$. tritici over these insects. C. quadricollis is cosmopolitan in distribution and has been found in wheat, rolled barley, rice, cacao and tobacco, and C. maculatus occurs throughout the tropical and subtropical regions of the world. It is a primary insect pest of stored legumes (Arbogast, 1991).

The health problems caused by $P$. tritici arise when they bite humans or other mammals. These bites cause painful itching skin lesions that have carned the name "hay-itch mite" for the more common species. This mite is also known as "strawitch mite" and its venom can also injure humans, causing dermatitis (Moser, 1975). The attack actually involves the mite piercing the skin with its sharp stylet-like mouthparts, and injecting venom that would normally be used to paralyze or kill its insect host. A patient often has hundreds of these bites, which can be very painful. Examples of such cases are in a worker handling straw in Australia (Southcott, 1976), and people handling hay, straw and grain in Israel (Yeruham et al., 1997), USA (Kinkle and Greiner, 1982; Walter and Landis, 1994) and Germany (Grob et al., 1998).

The mite $P$. tritici $i$ was observed feeding on larvae and pupae of C. quadricollis (Figure 1), and adults of $C$. maculates (Figure 2), with one or more mites per host (Figures 1 and 2). Soon after the parasitic attachment, toxins paralyzed larvae and adults these 


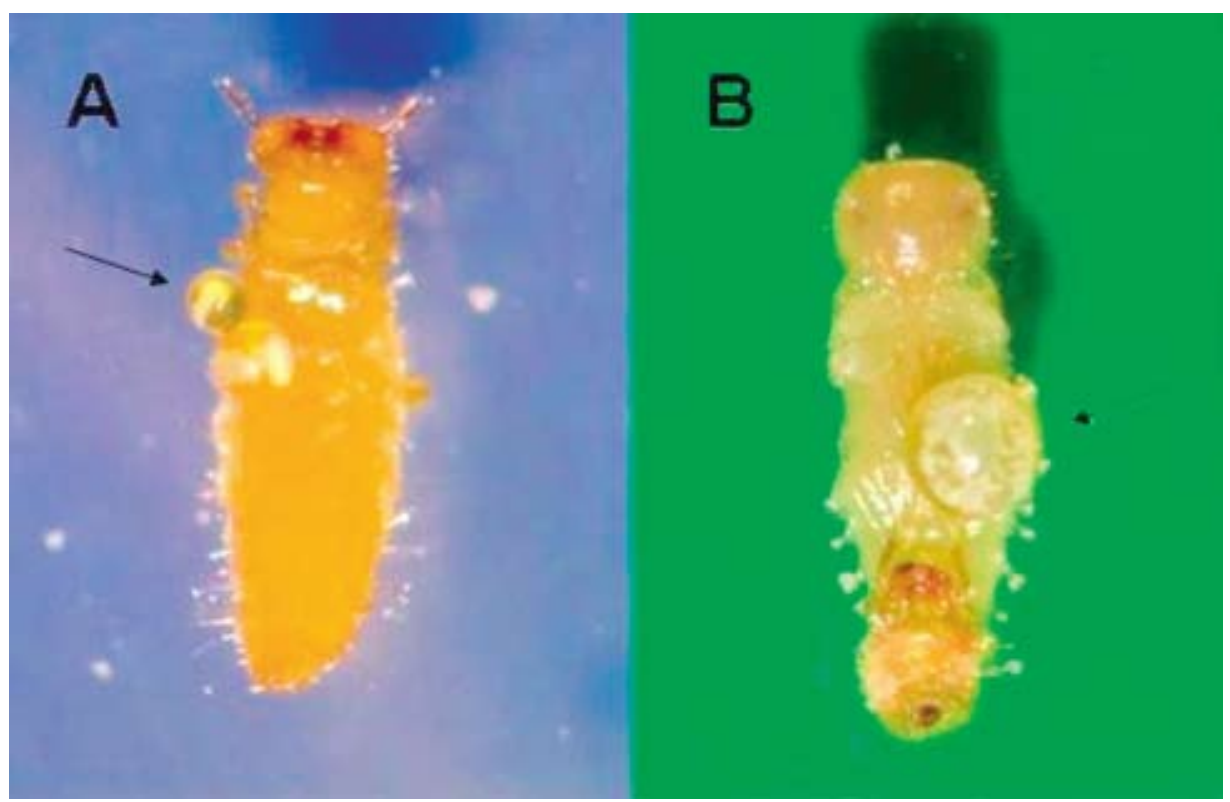

Figure 1. Cathartus quadricollis larvae (A) and pupae (B) attacked by physogastric females of Pyemotes tritici.

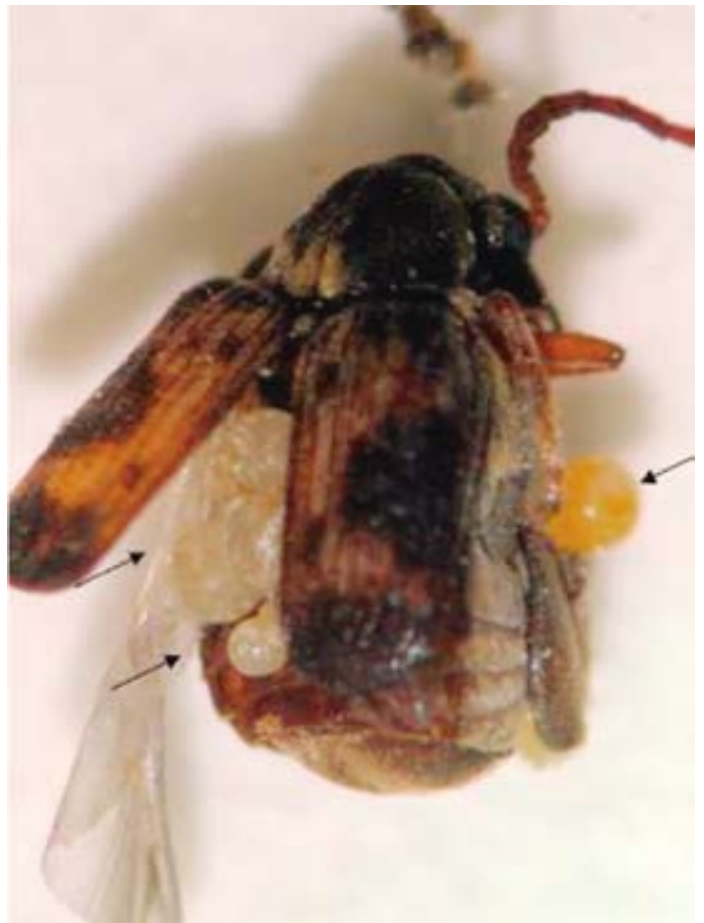

Figure 2. Callosobruchus maculatus adult attacked by physogastric females of Pyemotes tritici. species. Under the effect of parasitism by $P$. tritici, the hosts undergo marked color and shape changes. At this point, mites became yellowish, turning then brownish during feeding. P. tritici opisthosoma also changed and the female body enlarged, becoming spherical and milky (physogastric process).

P. tritici is a lethal problem for rearing mass of insects, since it can kill the whole population (Trivelli \& Velásquez, 1985), as observed in this present study. However, $P$. tritici can also be considered a strong biological control agent for $C$. quadricollis and $C$. maculatus, pursuing fast reproduction ability and efficient parasitism performance over these insects. In agreement with Hoschele \& Tanigoshi (1993), if $P$. tritici is used as a biological control agent, proper management will be needed because of this ability to administer painful bites. Thus, good control of the environment in which the mite is to be released is essential. A positive characteristic of $P$. tritici is that the mites are small enough not to have any adverse impact in the appearance of the product they are to protect. Once the pest has been eradicated, this mite species will die out as well. The commodity can be handled again after a sufficient safety period has elapsed. Therefore, the usefulness of $P$. tritici as a biological control agent seems promising and deserves additional investigation. 


\section{LITERATURE CITED}

ARBOGAST, R.T. 1991. Beetles: Coleoptera. In: GOHAM, J.R. (Ed.) Ecology and Management of Food-Industry Pests. FDA Technical Bulletin 4, Arlington: Association of Official Analytical Chemists, p. 131-176.

BRUCE, W.A. 1983. Mites as biological control agents of stored product pests. In: Hoy, M.A.; Knutson, L.; Cunningham, G.L. (Ed.). Biological control of pests of mites. Berkeley: University of California, p. 74-78.

BRUCE, W.A. 1984. Temperature and humidity: effects on survival and fecundity of Pyemotes tritici (Acari: Pyemotidae). International Journal of Acarology 10: 1355-1358.

BRUCE, W.A.; LECATO, G.L. 1979. Pyemotes tritici: potential biological control agent of stored-product insects. In: Rodriguez, J.G. (Ed.). Recent Advances in Acarology. New York: Academic Press, p. 213-220.

BRUCE, W.A.; LECATO, G.L. 1980. Pyemotes tritici: a potential new agent for biological control of the red imported fire ant, Solenopsis invicta. (Acari: Pyemotidae). International Journal of Acarology, 6: 271-274.

BRUCE, W.A.; WRENSCH, D.L. 1990. Reproductive potential, sex ratio, and mating efficiency of the straw itch mite (Acari: Pyemotidae). Journal of Economic Entomology, 83: 384-391.

CROSS, W.H.; MCGOVERN, H.W.; CROSS, E.A. 1975. Insect hosts of parasitic mites called Pyemotes ventricosus (Newport). Journal of Georgia Entomological Society, 10: 1-8.

CUNHA, U.S.; SILVA, E.S.; MORAES, G.J.; VENDRAMIN, J.D. 2006. Ocorrência do ácaro Pyemotes sp. (Acari: Pyemotidae) em criações de insetos em laboratório. Neotropical Entomology, 35: 563-565.

EVANS, G.O. 1992. Principles of Acarology. Wallingford: CAB International, $563 \mathrm{p}$.

GERSON, V.; SMILEY, R.L. 1990. Acarine biocontrol agents: an illustrated key and manual. New York: Chapman \& Hall, $174 \mathrm{p}$.

GROB, M.; DORN, K.; LAUTENSCHLAGER, S. 1998. Grain mites: a small epidemic caused by Pyemotes species. Hautarzt, 49: 838-843.

HOSCHELE, W.; TANIGOSHI, L.K. 1993. Pyemotes tritici (Acari: Pyemotidae), a potential biological control agent of
Anagasta kuehniella (Lepidoptera: Pyralidae). Experimental and Applied Acarology, 17: 781-792.

KINKLE, G.A.; GREINER, E.C. 1982. Dermatitis in horses and man caused by the straw itch mite. Journal of the American Veterinary Medical Association, 181: 467-469.

MOSER, J.C.; CROSS, E.A.; ROTON, L.M. 1971. Biology of Pyemotes parviscolyti (Acarina: Pyemotidae). Entomophaga, 16: 367-379.

MOSER, J.C. 1975. Biosystematic of the straw itch mite with special reference to nomenclature and dermatology. Transactions of the Royal Entomological Society of London, 127: 185-191.

OLIVEIRA, C.R.F.; MATOS, C.H.C. 2006. Infestação Natural de Pyemotes tritici (Lagréze-Fossat and Montagné) sobre Acanthoscelides obtectus (Say). Caatinga, 19: 426-429.

OLIVEIRA, C.R.F.; MATOS, C.H.C.; HATANO, E. 2007. Occurrence of Pyemotes sp. on Tuta absoluta (Meyrick). Brazilian Archives of Biology and Technology, 50:929-932.

SOUTHCOTT, R.V. 1976. Arachnidism and allied syndromes in the Australian region. Records of the Adelaide Children's Hospital, 1: 97-186.

TAWFIK, M.F.S.; EL-HUSSEINI, M.M.; AWADALLAH, K.T. 1981. Interactions between certain host larvae and the pyemoted ectoparasite, Pyemotes tritici. Bulletin de la Societe Entomologique d'Egypte, 63: 181-189.

TOMALSKI, M.D.; BRUCE, W.A.; TRAVIS, J.; BLUM, M.S. 1988. Preliminary characterization of toxins from the straw itch mite, Pyemotes tritici, which induce paralysis in the larvae of a moth. Toxicon, 26: 127-132.

TRIVELLI, H. DELL'O.; VELÁSQUEZ, C.J.A. 1985. Insectos que dañan granos y productos almacenados. Santiago: Oficina Regional de la FAO para América Latina y el Caribe. $142 \mathrm{p}$.

WALTER, E.D.; LANDIS, D.A. 1994. Straw itch mite, Pyemotes tritici, infestation in brome seed related to acute dermatitis in Michigan granary workers. Great Lakes Entomologist, 27: 125-128.

YERUHAM, I.; ROSEN, S.; BRAVERMAN, Y. 1997. Dermatitis in horses and humans associated with straw itch mites (Pyemotes tritici) (Acarina: Pyemotidae). Acarologia, 38:161-164. 